\title{
Bankruptcy Prediction Model using Logit Regression in the Automotive Sector
}

\author{
Nonthawat Sricharoenchit ${ }^{1}$, Surang Hensawang ${ }^{2}$ \\ \{bsnonthawat@hotmail.com ${ }^{1}$, fbussum@ku.ac.th $\left.{ }^{2}\right\}$ \\ Kasetsart University, Kasetsart International MBA Program, \\ 50 Ladyao, Chatuchak, Bangkok 10900, THAILAND ${ }^{1}$ \\ Kasetsart University Faculty of business Administration, \\ 50 Ladyao, Chatuchak, Bangkok 10900, THAILAND ${ }^{2}$
}

\begin{abstract}
This research aims to develop the bankruptcy prediction model tool for financial risk management in the automotive industry in Thailand. The study will research the relationship between the company's status and independent variables that include financial ratios and corporate governance. These factors will be used to find the model that can separate the automotive companies into two groups that are bankruptcy Company and non-bankruptcy Company with a high accuracy rate. The data used in this study are divided into two sample groups, including 56 companies with bankruptcy situations and 101 companies without bankruptcy situations. The data was based on the financial statement in the DBD Data Warehouse, and the status of a company contained in the website using current financial statements and using three-period historical data to define the prediction model.
\end{abstract}

The result shows that the model achieved an overall accuracy rate of 75.40 percent for predicting the company's status in the automotive industry by using seven independent variables. These are the percentage of Thai shareholders, the share of major shareholders, the number of shareholders, the number of directors, current ratios, operation expense to total revenue ratios, and debt to asset ratios. Therefore, this model can accurately predict the bankruptcy of the company in the Thailand automotive industry.

Keywords: Bankruptcy prediction, Logit regression, Financial Ratios, Corporate Governance, Automotive industry. 


\section{Introduction}

Nowadays, companies in Thailand have a high occurrence of bankruptcy. The percentage of non-performing loans (NPL) in Thailand in 2014- 2019 grew higher each year. Figure 1 shows the trend of non-performing loans increasing every year.

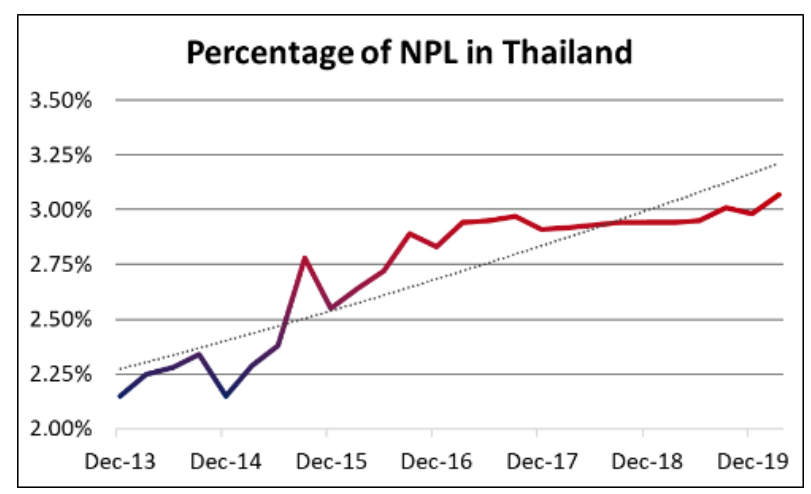

Fig. 1. Percentage of non-performing loan in Thailand.

The automotive industry comprises a wide range of companies and organizations involved in the design, development, manufacturing, marketing, and selling of motor vehicles. It is one of the world's largest economic sectors by revenue. The automotive industry does not include enterprises dedicated to the maintenance of automobiles following delivery to end-users, such as automobile repair shops and motor fuel filling stations.

In 2017, the automotive industry in Thailand was the largest in Southeast Asia and the 12th largest in the world. The Thai automotive industry has an annual output of near two million vehicles. After 2018, exports of auto and auto parts continued to slow, as reflected by an export value that remains below its trend.

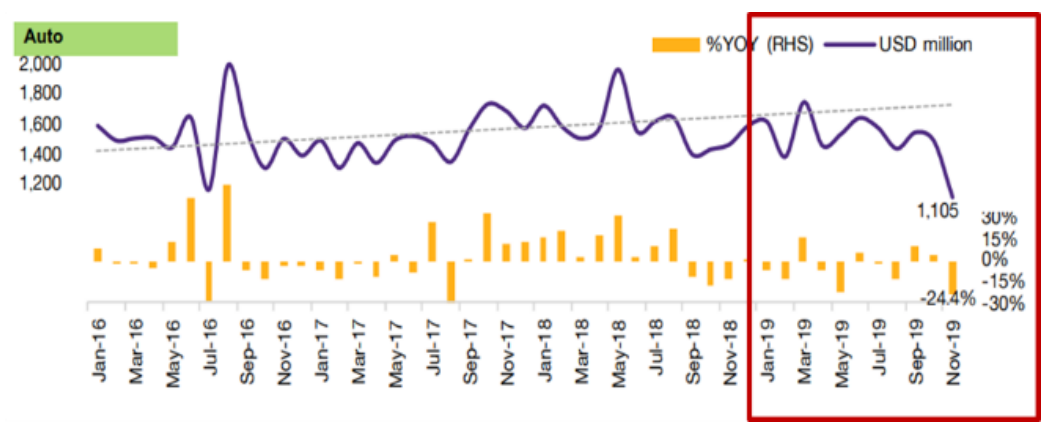

Fig. 2. Value and growth of auto, seasonally adjusted. 


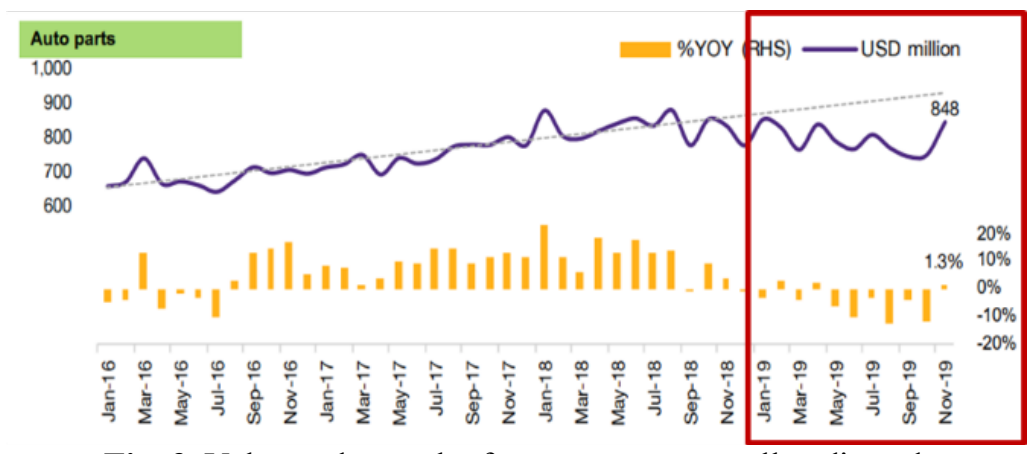

Fig. 3. Value and growth of auto parts, seasonally adjusted.

The value of automotive exports accounted for 14.9 percent of the total export value in 2018 weakened following persistent slowdowns in the global automotive market since September 2018. Currently, automotive exports continue to drop, evident from an export value that is still below the trend line. During the first 11 months of 2019, the value of automotive exports shrank by 5.1 percent year over year, while auto parts exports shrank by -4.8 percent year over year.

From car sales data in Thailand collected by Toyota Company as of April 2020 said car sales reduced in the first four months of 2020 compared to the first four months of 2019. The biggest companies in the automotive industry, twelve companies in Thailand, have average sales dropped about 35 percent.

\section{Review of Literature}

\subsection{Bankruptcy}

"Bankruptcy is the legal proceeding involving a person or business that is unable to repay outstanding debts. The bankruptcy process begins with a petition filed by the debtor or creditors. All of the debtor's assets are measured and evaluated, and the assets may be used to repay a portion of the outstanding debt. (Alicia Tuovila, 2020). '

Bankruptcy act in Thailand provides bankruptcy, meaning that adjudged bankrupt on account of or in connection with the commission of an offense of misappropriation or cheating under the Penal Code or the commission of the offense amounting to providing a loan constituting public fraud under the law on loans constituting public fraud. From section 9, the creditor may only initiate 
a bankruptcy action against the debtor if the debtor becomes insolvent. Meaning of debtor is a natural person is indebted to one or more plaintiff creditors for not less than one million baht, or the debtor who is a juristic person is indebted to one or more plaintiff creditors for not less than two million baht and the definite amount of such debt is determinable, whether it becomes due forthwith or at a future date.

"Bankruptcy is a legal process overseen by federal bankruptcy courts. It's designed to help individuals and businesses eliminate all or part of their debt or help them repay a portion of what they owe. It may help you get relief from your debt, but it's important to understand that declaring bankruptcy has a serious, long-term effect on your credit. Bankruptcy will remain on your credit report for 7-10 years, affecting your ability to open credit card accounts and get approved for loans with favorable rates. Bankruptcy can be a complex process, and the average person probably isn't equipped to go through it alone. Working with a bankruptcy attorney can help ensure your bankruptcy goes as smoothly as possible and complies with all the applicable rules and regulations governing bankruptcy proceedings. You'll also have to meet some requirements before you can file for bankruptcy. You'll need to demonstrate you can't repay your debts and also complete credit counseling with a government-approved credit counselor. The counselor will help you assess your finances, discuss possible alternatives to bankruptcy, and help you create a personal budget plan. (David Haynes, 2019)."

The debt cycle framework is the cycle that causes debt. It begins with a shortage of cash, turning to use credit to buy something. It makes the debt grow and require higher payments, while income does not change, but has to be paid in higher installments. This situation will impact a shortage of cash again. Bankruptcy will occur when you cannot pay the payments anymore.

\subsection{Corporate governance}

"Corporate governance is the system of rules, practices, and processes by which a company is directed and controlled. It essentially involves balancing the interests of the many stakeholders in a company, including its shareholders, staff, customers, suppliers, financiers, government, and the community. It provides the framework for attaining the company's objectives (Werder, 2015)."

The purpose of the corporate governance framework is to improve and systematize our company's governance, make it more transparent, and demonstrate our company's commitment to good corporate governance by developing and furthering. This corporate governance framework's key success 
includes vision, mission, strategy, objective, and smart goals. The meaning of each key success as follows:

The vision is the future position of the company, which then provides the purpose. The strong vision statement helps teams focus on what matters the most for their company.

The mission is what you do, or the core of the business, and from it comes to the objectives and finally, what it takes to reach those objectives.

The strategy is an action that managers take to attain one or more of the organization's goals.

The objective is a result that a company aims to achieve. It also includes the strategies that people will use to get there.

Smart goals are part of every aspect of business and provide a sense of direction, motivation, a clear focus, and clarify importance.

The corporate governance framework is based on six components that are a board of directors and committees, legal and regulatory framework, organizational hierarchy, monitoring, and internal control, transparency and accountability, and policies and procedures.

\subsection{Financial ratio}

"Financial ratios are relationships determined from a company's financial information and used for comparison purposes. Tracking various ratios over time is a powerful means of identifying trends in their early stages (INC, 1997). " There are four types of financial ratios: profitability ratios, liquidity ratio, leverage ratio, and efficiency ratio.

"Profitability ratios are a class of financial metrics used to assess a business's ability to generate earnings relative to its revenue, operating costs, balance sheet assets, and shareholders' equity over time, using data from a specific point in time.

Liquidity ratios are an important class of financial metrics used to determine a debtor's ability to pay off current debt obligations without raising external capital. Liquidity ratios measure a company's ability to pay debt obligations and its margin of safety.

Leverage ratio is any one of several financial measurements that look at how much capital comes in the form of debt (loans) or assesses the ability of a company to meet its financial obligations. The leverage ratio category is important because companies rely on a mixture of equity and debt to finance their operations. Knowing the amount of debt held by a company is useful in evaluating whether it can pay its debts off as they come due. 
The efficiency ratio is typically used to analyze how well a company uses its assets and liabilities internally.(Adam Hayes, 2019)"

\subsection{Logit regression}

"Logit regression is the appropriate regression analysis to conduct when the dependent variable is binary. Like all regression analyses, the logit regression is a predictive analysis. It is used to describe data and to explain the relationship between one dependent binary variable and more than one independent variable (Statistics Solutions, 2020)." Assumptions of logit regression are including the dependent variable should be binary, each independent variable should have low multicollinearity, independent variables should be in the log odds term, and the minimum sample size is 10 .

Multicolinearity test by the variance inflation factor (VIF) that is calculated from:

$$
\mathrm{VIF}=\frac{1}{1-\mathrm{R}^{2}}
$$

Where $\mathrm{R}^{2}$ is the coefficient of determination of the regression equation

The probability to happen an event is calculated from:

$$
P_{y}=\frac{e^{\alpha+\beta_{1} x_{1}+\cdots+\beta_{p} x_{p}}}{1+e^{\alpha+\beta_{1} x_{1}+\cdots+\beta_{p} x_{p}}}
$$

Where $\mathrm{P}_{\mathrm{y}}$ refer probability to happen an event

$\alpha$ is intercept (constant value)

$\beta_{\mathrm{p}}$ is slope at factor $\mathrm{p}$ (coefficient)

$\mathrm{x}_{\mathrm{p}}$ is independent variable at factor $\mathrm{p}$

The logit model will show in term of logarithm odds or $\log \operatorname{Exp}(B)$ as follow;

$$
\log \left(\frac{P_{y}}{Q_{y}}\right)=\alpha+\beta_{1} x_{1}+\cdots+\beta_{p} x_{p}+\varepsilon
$$

Where $\mathrm{Q}_{\mathrm{y}}$ refer probability to not happen an event

$\varepsilon$ indicates the error of prediction model

Odds or $\operatorname{Exp}(\mathrm{B})$ is the ratio between probability to happen an event and probability to not happen an event.

If odds ratio $>1$ means the probability to happen an event is increases in term of times. 
odds ratio $<1$ means the probability to happen an event is decreases in term of percentage that is calculated from:

$$
\text { Decreasing probability }=(1 \text {-odds }) \times 100
$$

To include as few variables as possible because each irrelevant variables decreases the precision of the estimated coefficients and predicted values. There have three methods to select the independent variables into the model.

Firstly, enter method, a procedure of this method for variable selection in which all variables in a block are entered in a single step into the model. The user will decide to exclude variables by a look at a significant level.

Secondly, forward stepwise, this method is often used to provide an initial screening of the candidate variables when a large group of variables exists. The forward selection method is simple to define. It is beginning with no candidate variables in the model. Select the variable that has the highest RSquared. At each step, select the candidate variable that increases R-Squared the most. Stop adding variables when none of the remaining variables are significant.

Lastly, backward stepwise, the problem with this method is that the models selected by this procedure may include variables that are not really necessary. The user sets the significance level at which variables can enter the model. The backward selection model starts with all candidate variables in the model. At each step, the variable that is the least significant is removed. This process continues until no non-significant variables remain.

The logit regression model will provide the probability to happen an event and parameter estimated from the maximum likelihood method. The results will show the model equation and accuracy rate of the model with type 1 error and type 2 error.

Type 1 error is also known as a false positive and occurs when a researcher incorrectly rejects a true null hypothesis. It means that your report that your findings are significant when, in fact, they have occurred by chance.

Type 2 error is also known as a false negative and occurs when a researcher fails to reject a null hypothesis, which is really false. Here a researcher concludes there is not a significant effect when actually there really is.

\subsection{Previously Research}

\section{Corporate governance}


"It can be evident that an early warning system cannot be developed without incorporating the corporate governance characteristics. The reason is that poor corporate governance can increase the probability of corporate failure even for firms with good financial performances. (Nisansala Wijekoon and A. Abdul Azeez, 2015)."

"The relationship between corporate governance and firm performance for the Karachi Stock Market. To proxy for firm-level governance, we use a rating system to evaluate the stringency of a set of governance practices and cover various governance categories. Our results document a positive and significant relation between the quality of firm-level corporate governance and firm performance. (Attiya Y. Javed and Robina Iqbal, 2007). ”

\section{Financial ratio}

"Employed logistic regression analysis, the results of this study were that four independent variables, namely, Net Profit Margin (NPM), Basic Earning Power (BEP), Interest coverage Ratio (ICR), and Cash Flow from Operating Activities to Total Debt Ratio (CFOTD), statistical significantly affected the prediction. (Narumon Jaisaen, 2016)."

"This study aims to investigate the impact of bank-specific factors which include the liquidity, credit, capital, operating expenses and the size of commercial banks on their performance, which is measured by return on average assets (ROAA) and return on average equity (ROAE). The results imply that ratios employed in this study have different effects on the performance of banks in both countries, except credit and capital ratios. Operating ratios influence performance of banks in China, but this influence is not true for Malaysian banks regardless of the measure of performance. (Rasidah Mohd Said1 and Mohd Hanafi Tumin, 2011)." 


\section{Logit regression}

"The prediction model based on Logistic Regression Analysis yields 3 independent variables: Total Liabilities to Total Assets Ratio (TLTA), Current Assets to Total Assets Ratio (CATA) and Earnings before Interest and Tax to Total Assets Ratio (EBTA). The model is correctly classified the potential delisted and non-potential delisted cases 1 year in advance up to $99.53 \%$, also correctly classified $98.60 \%$ in the next 2 years and follow by $97.21 \%$ in the next 3 years. (Attapong Peeracheir, 2018). "

"The result found that the efficiency of the regression equation used to predict companies that 89.50 of financial strong companies, listed in the SET were predicted correctly. Moreover, $72.10 \%$ of financial problem companies were predicted correctly. On average, $76.40 \%$ of both types of companies were predicted by using Logistics Regression correctly. (Jakkapat Phongpatra and Bundit Pungniran, 2018). "

\subsection{Conceptual Framework}

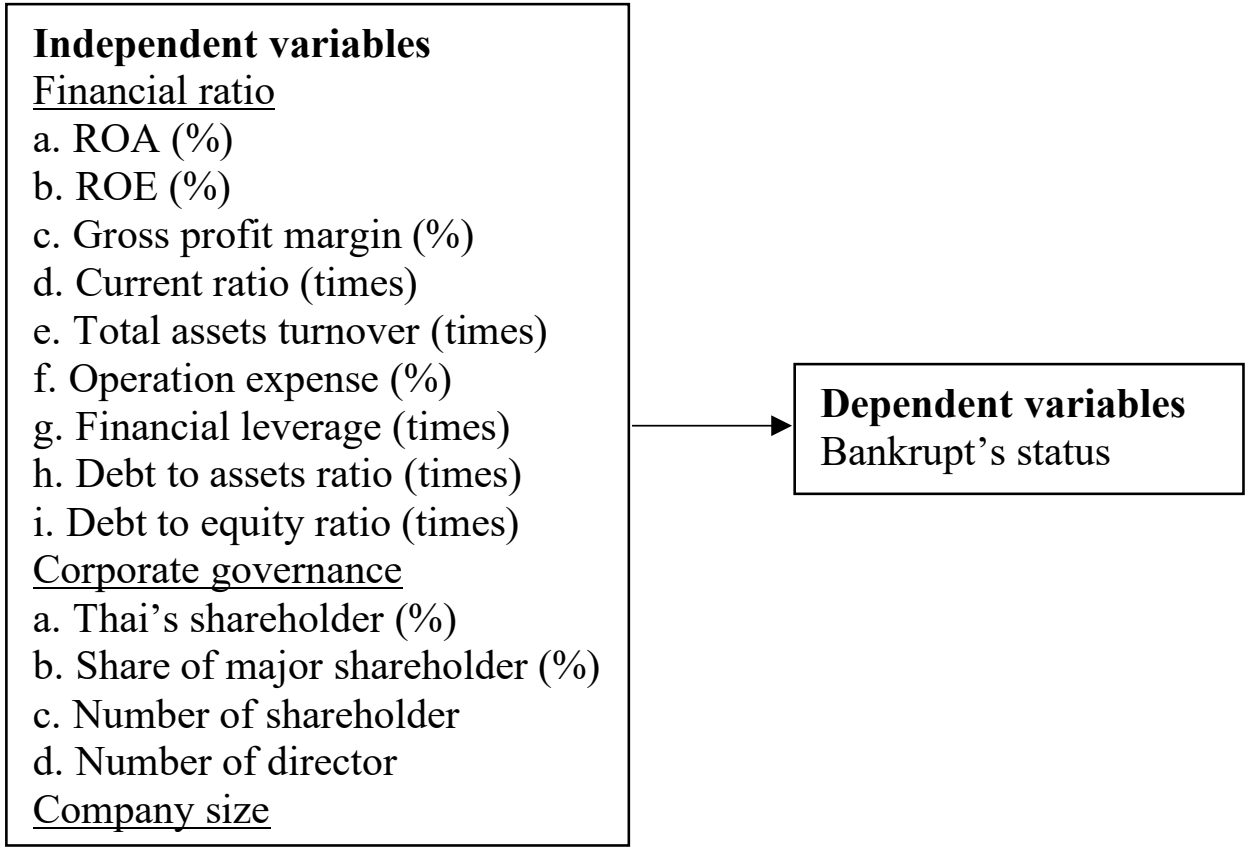




\section{Methodology}

\subsection{Data Collection Procedures}

The data sample for this research consists of Thai automotive corporations that filed for bankruptcy in the period from January 2016 to December 2019 as listed in the DBD Data warehouse and used three-years recently data to create the logit regression model. The data sample includes company size, corporate governance, and financial ratios in bankruptcy and non-bankruptcy companies to analyze characteristics in each group.

The data from DBD Data warehouse are provided company name, bankruptcy status, financial ratio, and corporate governance. The data collected in a three-period historical for 56 companies in a bankrupt situation and 101 companies in a non-bankrupt situation. Total observation in this research is 471 observations divided into bankrupt situation 168 observations and non-bankrupt situation 303 observations.

The initial financial ratios, corporate governance, and size were a set of 14 factors including return on assets, return on equity, gross profit margin, current ratio, total assets turnover, operation expense to total revenue ratio, financial leverage, debt to asset ratio, debt to equity ratio, company's size, Thai's shareholder, share of major shareholder, number of shareholder, and number of director as show in Table 1.

Table 1. Independent variables.

\begin{tabular}{ccc}
\hline Code & Ratios & Definition \\
\hline ROA & Return on Assets (\%) & Net profit(loss)/Total assets*100 \\
ROE & Return on Equity (\%) & Net profit(loss)/Total equity*100 \\
GPM & Gross Profit Margin (\%) & Gross profit(loss)/ Total revenue*100 \\
CRR & Current Ratio (times) & Current assets/Current liabilities \\
AT & Total Assets Turnover (times) & Net sales/Average total assets \\
OPE & Operation Expense to Total Revenue & (Operating expenses- \\
& Ratio (\%) & depreciation)/Total revenue*100
\end{tabular}




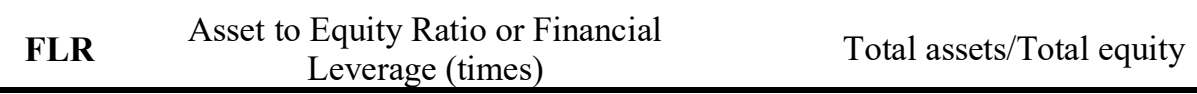

Table 1. Independent variables (cont.).

\begin{tabular}{|c|c|c|}
\hline Code & Ratios & Definition \\
\hline DAR & Debt to Asset Ratio (times) & Total liability/Total assets \\
\hline DER & Debt to Equity Ratio (times) & $\begin{array}{c}\text { Total liability/Total shareholder's } \\
\text { equity }\end{array}$ \\
\hline Size & Total assets & $\begin{array}{l}\text { Total assets less than or equal } 50 \mathrm{M}=1 \text {, } \\
\text { Total asset more than } 50 \mathrm{M}=0\end{array}$ \\
\hline THD & Thai's shareholder (\%) & $\begin{array}{c}\text { Thai's shareholder/Total } \\
\text { shareholder*100 }\end{array}$ \\
\hline MHD & Share of major shareholder $(\%)$ & $\begin{array}{l}\text { Share of main shareholder/Total } \\
\text { share*100 }\end{array}$ \\
\hline SHD & Number of shareholder & Number of shareholder \\
\hline ODT & Number of director & $\begin{array}{l}\text { One director }=1, \text { More than one } \\
\text { director }=0\end{array}$ \\
\hline
\end{tabular}

Table 2. Dependent variable.

\begin{tabular}{cc}
\hline Group & Variable \\
\hline Bankrupt & 1 \\
Non-bankrupt & 0 \\
\hline
\end{tabular}

\subsection{Data Analysis}

This research uses the SPSS program to analyze the data and find the logit regression model using three-period historical data.

Firstly, the descriptive statistic was used in this analysis to analyze the characteristic of independent variables for each group. The output shows the factor as a number of observations in this research, mean, Std. Deviation.

Secondly, the factor correlation test finds the direction of each independent variable to the dependent variable: company status by a coefficient of factors. follows:

Lastly, the Logit regression model was used to classify the group as

$$
P_{y}=\frac{e^{\alpha+\beta_{1} x_{1}+\cdots+\beta_{p} x_{p}}}{1+e^{\alpha+\beta_{1} x_{1}+\cdots+\beta_{p} x_{p}}}
$$

Where $\mathrm{P}_{\mathrm{y}}$ refer probability to happen an event

$\alpha$ is intercept (constant value)

$\beta_{\mathrm{p}}$ is slope at factor $\mathrm{p}$ (coefficient) 
$\mathrm{x}_{\mathrm{p}}$ is independent variable at factor $\mathrm{p}$

Multicollinearity test: Test the relationship between independent variables by using the Variance Inflation Factor (VIF) should lower than 10. The analysis of this part is to predict the status of companies in the automotive industry. Enter the method used to exclude the factors that no significant out in this research.

\subsection{Hypotheses}

\section{Wald Statistic test}

$\mathrm{H}_{0}: \beta_{\mathrm{i}}=0 ; \mathrm{i}=1,2,3, \ldots, \mathrm{p}$

(Independent variable is not impact to changing of company status)

$\mathrm{H}_{1}: \beta_{\mathrm{i}} \neq 0 ; \mathrm{i}=1,2,3, \ldots, \mathrm{p}$

(Independent variable is impact to changing of company status)

\section{Omnibus test}

$\mathrm{H}_{0}: \beta_{1}=\beta_{2}=\beta_{3}=\cdots=\beta_{\mathrm{p}}$

(Model is not depend on independent variables)

$\mathrm{H}_{1}$ : Model depend on $\beta_{\mathrm{i}}$ at least one $; \mathrm{i}=1,2,3, \ldots, \mathrm{p}$

(Model is depend on independent variable at least one factor) 


\section{Results and Discussion}

\subsection{Results}

This study uses logit regression to predict the status of automotive companies, find the correlation between independent variables and dependent variables, and find the factors that impact the company's situation. The sample size is 157 companies divided into two groups that are bankruptcy 56 companies, which are 36 percent and non-bankruptcy 101 companies, which are 64 percent with nine financial ratios and five corporate governance by using three-period historical data. The observation is 471 observations divided to nonbankrupt 303 observations and bankrupt 168 observations.

\section{Descriptive statistic}

Table 3 shows the descriptive statistic between the bankrupt company group and the non-bankrupt company group.

Table 3. Descriptive statistic.

\begin{tabular}{c|ccc|ccc}
\hline & \multicolumn{3}{|c|}{ 0 (non-bankrupt) } & \multicolumn{3}{c}{ 1 (bankrupt) } \\
\hline Factor & $\mathrm{N}$ & Mean & Std. Dev & $\mathrm{N}$ & Mean & Std. Dev \\
\hline Size & 303 & 0.9 & 0.3 & 168 & 1.0 & 0.2 \\
THD & 303 & 0.8 & 0.3 & 168 & 1.0 & 0.1 \\
MHD & 303 & 0.6 & 0.2 & 168 & 0.7 & 0.2 \\
SHD & 303 & 3.7 & 1.5 & 168 & 4.1 & 3.4 \\
ODT & 303 & 0.4 & 0.5 & 168 & 0.7 & 0.5 \\
ROA & 303 & -1.7 & 28.1 & 168 & -16.7 & 43.6 \\
ROE & 303 & 9.0 & 37.9 & 168 & 11.7 & 175.7 \\
GPM & 303 & -735.1 & 5112.9 & 168 & -9492.9 & 39334.4 \\
CRR & 303 & 33.9 & 88.7 & 168 & 84.7 & 304.3 \\
AT & 303 & 1.9 & 2.8 & 168 & 1.2 & 2.5 \\
OPE & 303 & 833.8 & 5113.1 & 168 & 8578.5 & 37863.1 \\
FLR & 303 & 5.0 & 23.3 & 168 & 7.3 & 49.2 \\
DAR & 303 & .9 & 1.8 & 168 & 135.9 & 763.0 \\
DER & 303 & 3.9 & 23.3 & 168 & 6.3 & 49.2 \\
\hline
\end{tabular}




\section{Multicollinearity test}

Check the multicollinearity of each factor for excluding the factors that are high inter-correlation or VIF value more than 10 .

Table 4. Multicollinearity test.

\begin{tabular}{cc}
\hline Model & Collinearity Statistics \\
& VIF \\
\hline (Constant) & 1.176 \\
Size & 1.270 \\
THD & 1.239 \\
MHD & 1.172 \\
SHD & 1.336 \\
ODT & 1.125 \\
ROA & 1.012 \\
ROE & $>999.999^{*}$ \\
GPM & 1.025 \\
CRR & 1.231 \\
AT & 1.046 \\
OPE & $799.694^{*}$ \\
FLR & 1.076 \\
DAR & $800.125^{*}$ \\
DER & \\
\hline
\end{tabular}

* Excluding GPM, FLR, DER from the model because of inter-correlation problem.

\section{Factors correlation}

To run the logit regression by select the status of companies as the dependent variable and rest factors as the independent variable.

Table 5. Variables in equation.

\begin{tabular}{ccc}
\hline & B & $\operatorname{Exp}(\mathbf{B})$ \\
\hline Size & .137 & 1.146 \\
THD & 3.315 & 27.516 \\
MHD & 1.375 & 3.956 \\
SHD & .256 & 1.291 \\
ODT & 1.553 & 4.726 \\
\hline
\end{tabular}


Table 5. Variables in equation (cont.).

\begin{tabular}{ccc}
\hline & B & $\operatorname{Exp}(\mathbf{B})$ \\
\hline ROA & -.003 & .997 \\
ROE & .000 & 1.000 \\
CRR & .002 & 1.002 \\
AT & -.052 & .949 \\
OPE & .000 & 1.000 \\
DAR & .033 & 1.034 \\
Constant & -6.724 & .001 \\
\hline
\end{tabular}

Analyze the correlation of each independent variable and the company's status by the coefficient in each factor. It can separate the direction of correlation into two groups.

There is a positive correlation with the probability of bankruptcy, including size, THD, MHD, SHD, ODT, CRR, and DAR. When the independent variable increases, the probability of bankrupt will also increase.

Table 6. Positive correlation.

\begin{tabular}{lll}
\hline \multicolumn{1}{c}{ Independent Variable } & \multicolumn{1}{c}{ Change } & \multicolumn{1}{c}{ Probability impact } \\
\hline Size & $=1$ (small) & Increases by 1.146 times \\
Thai's shareholder (\%) & + one unit & Increases by 27.516 times \\
Share of main shareholder (\%) & + one unit & Increases by 3.956 times \\
Number of shareholder & + one unit & Increases by 1.291 times \\
Number of director & $=1$ (one director) & Increases by 4.726 times \\
Current Ratio (times) & + one unit & Increases by 1.002 times \\
Debt to Asset Ratio (times) & + one unit & Increases by 1.034 times \\
\hline
\end{tabular}


Negative correlation with the probability of bankruptcy, including ROA and AT. When the independent variable increases, the probability of bankrupt will decrease.

Table 7. Negative correlation.

\begin{tabular}{lll}
\hline \multicolumn{1}{c}{ Independent Variable } & \multicolumn{1}{c}{ Change } & Probability impact \\
\hline Return on Assets (\%) & + one unit & Decreases by 0.3 percent \\
Total Assets Turnover (times) & + one unit & Decreases by 5.1 percent \\
\hline
\end{tabular}

\section{Hypotheses test}

When using the enter method to exclude the factor that non-significant out by set confidence level at $95 \%$, the independent variables that are significant to the model including Thai's shareholder, Share of main shareholder, number of shareholder, number of director, current ratio, operation expense to total revenue ratio, and debt to asset ratio.

Table 8. Omnibus test of model coefficients.

\begin{tabular}{cccc}
\hline & Chi-square & df & Sig. \\
\hline Step & 143.271 & 7 & .000 \\
Block & 143.271 & 7 & .000 \\
Model & 143.271 & 7 & .000 \\
\hline
\end{tabular}

$\mathrm{P}$-value $<0.05$, Reject $\mathrm{H}_{0}$ means the model depend on $\beta_{\mathrm{i}}$ at least one.

Table 9. Model summary.

\begin{tabular}{cccc}
\hline Step & -2Log likelihood & Cox \& Snell R Square & Negelkerke R Square \\
\hline 1 & 470.432 & .262 & .360 \\
\hline
\end{tabular}

Cox \& Snell R Square $=.262$ and Negelkerke R Square $=.360$ 


\section{Logit regression model}

The variables in the equation table show the coefficients, standard errors, the Wald test statistic with associated degrees of freedom and p-values, and the exponential coefficient or odds ratio.

Table 10. Variables in equation.

\begin{tabular}{ccccccc}
\hline & B & S.E. & Wald & df & Sig. & $\operatorname{Exp(B)}$ \\
\hline THD & 3.202 & .814 & 15.489 & 1 & .000 & 24.589 \\
MHD & 1.332 & .541 & 6.070 & 1 & .014 & 3.788 \\
SHD & .265 & .077 & 11.805 & 1 & .001 & 1.304 \\
ODT & 1.549 & .275 & 31.796 & 1 & .000 & 4.707 \\
CRR & .002 & .001 & 7.932 & 1 & .005 & 1.002 \\
OPE & .00007 & .000 & 4.014 & 1 & .045 & 1.000 \\
DAR & .031 & .014 & 5.079 & 1 & .024 & 1.031 \\
Constant & -6.580 & .942 & 48.739 & 1 & .000 & .001 \\
\hline
\end{tabular}

P-value $<0.05$ in each factor, Reject $\mathrm{H}_{0}$ means each factor are impact to changing of company status. The equation of this model is:

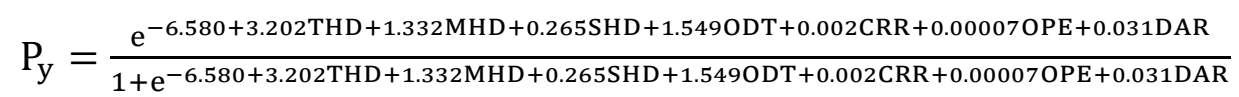

This equation is used to predict the status of the automotive companies by find the probability to bankrupt.

\section{Accuracy rate}

The logit regression model compares the model's predictions to observed outcomes in the data - the classification table for the calibration and validation samples of bankruptcy companies displayed in Table 11.

Table 11. Classification table.

\begin{tabular}{|c|c|c|c|c|}
\hline \multirow{2}{*}{\multicolumn{2}{|c|}{ Observed }} & \multirow{2}{*}{\multicolumn{3}{|c|}{ Predicted }} \\
\hline & & & & \\
\hline & & 0 & 1 & Percentage Correct \\
\hline \multirow[t]{2}{*}{ Status } & 0 & 264 & 39 & 87.1 \\
\hline & 1 & 77 & 91 & 54.2 \\
\hline \multicolumn{2}{|c|}{ Overall Percentage } & & & 75.4 \\
\hline
\end{tabular}


Accuracy Rate in this model is $75.4 \%$. It predict that the company will not bankrupt with $87.1 \%$ accuracy and go bankrupt with $54.2 \%$ accuracy. Type 1 error is $12.9 \%$ and type 2 error is $45.8 \%$.

\subsection{Discussion}

The logit regression model that used to predict the company's status in Thailand automotive industry by setting the significant level at 0.05 is the model that is using factors including Thai's shareholder (\%), Share of main shareholder (\%), Number of shareholders, Number of directors, Current Ratio (times), Operation Expense to Total Revenue Ratio (\%), and Debt to Asset Ratio (times). The accuracy rate of this model is 75.4 percent. This accuracy rate is close to Jakkapat Phongpatra and Bundit Pungniran (2018) research that has an accuracy rate of around 76 percent.

To manage and control these factors is important to prevent financial risk and reduce the probability of bankruptcy. Consideration of corporate governance is as important as financial ratios. A foreign shareholder will increase your business perspective and expand your business internationally more easily. Giving too much power to only one shareholder may result in corruption. On the other hand, too many shareholders may cause them to work slowly due to slow decisions. More than one director will be more beneficial to the company as it can brainstorm ideas and consult for better ways for the company. In terms of a financial ratio, the company should provide awareness of the current ratio and debt to asset ratio because these ratios can balance your asset and liability in the long term and short term. It should control by the expert team. The expense of the company is another important factor in preventing bankruptcy situation. The company should control the company's expenses and use it efficiently. 


\section{Conclusions and Recommendations}

This research aimed to predict the status of automotive companies in Thailand, whether there is a chance of bankruptcy or not, and used to prevent and control the risk of companies in the automotive industry.

\subsection{Conclusion}

This logit regression was estimated to examine such a model with a statistical significance of 0.05 . The model has an accuracy rate as $75.4 \%$ by using seven independent variables that are Thai's shareholder (\%), Share of main shareholder (\%), Number of shareholders, Number of directors, Current Ratio (times), Operation Expense to Total Revenue Ratio (\%), and Debt to Asset Ratio (times).

\subsection{Recommendations}

\section{Company in automotive industry perspective}

(1) The company has too few large shareholders that may cause corruption, should be internal audits regularly. On the other hand, the company has too many shareholders may not be effective.

(2) There should include foreign shareholders as well for a more different perspective.

(3) Consider more about the number of directors. There should be more than one to discuss together the company's guidelines. much.

(4) The company should control the expenses of the company, not too

(5) Debt to asset ratio can be used as one of the trigger points to prevent the risk of bankruptcy before it happens because this ratio will balance your asset and liability.

(6) Liquidity in terms of liquid or current assets in recession period is not preferable because liquid assets such as cash earn less. Therefore, it leads to probability of bankruptcy

(7) Inconsistent with monitoring mechanism by major shareholders. Imply that free float should be suitable to automotive Thai companies. Free float implies to more liquidity in term of stock exchange. 


\section{Suggestion for further study}

(1) Further studies should be conducted in other industries

(2) Using other methods of prediction to compare the accuracy of the predictions

(3) Increasing the independent variables used to predict bankruptcy.

(4) This research covers companies in the automotive industry group in Thailand only. The result may be different from the predictions of foreign countries or other industries.

\section{Acknowledgments}

I would like to start by thanking my adviser, Assistant Professor Surang Hensawang, Ph.D. From giving her valuable guidance at the beginning of this research, expert suggestions, and advice on every step of this work. It made this research complete in a timeline. Without her able guidance, this thesis would not have been possible, and I shall eternally be grateful to her for her assistance. Thank you to Assistant Professor Nirundon Tapachai for providing advice and knowledge in all areas throughout the KIMBA program for two years.

Thank you my KIMBA friends, for helping and giving advice, especially in Ms. Natthaphat Chada, she always reminds me about the timeline of this research and helps me get the data for this research. I also want to thank you to the KIMBA office for checking the schedule and all the help that is given. I would like to thank the KIMBA project that created this good program to makes me get to know KIMBA friends and professors that give knowledge and good advice to me.

I would like to thank my boss and my colleagues at Siam Commercial Bank PCL, my previous workplace, and Thai Military Bank PCL, my current workplace, to understand and let me do this research until it complete.

Lastly, I sincerely thank my family for every support when I was feeling tired or discouraged, care about my personal attention, and taking care of every detail. Without their loving upbringing and nurturing, I couldn't have come this far without their support. 


\section{References}

[1] Altman, EI. Financial ratios, discriminant analysis and the prediction of corporate bankruptcy. Journal of financial 1968: 4(1): 589-609.

[2] Attapong Peeracheir. Prediction model of potential delisted companies in the Stock Exchange of Thailand. Journal of Management 2018: 7(2): 8-22.

[3] Attiya Y. Javed and Robina Iqbal. The Relationship between Corporate Governance Indicators and Firm Value: A Case Study of Karachi Stock Exchange. PIDE-Working Papers 2007:14, Pakistan Institute of Development Economics; 2007.

[4] Beaver, WH. Financial ratios as predictors of failure. Journal of Accounting Research 1966: 4(2): 71-111.

[5] Chalongrath, Wichitra. Corporate Governance, Bankruptcy Risk and Firm Performance of Thai Listed Companies. Humanities and Social Sciences Journal of Graduate School. 2018: 12(1).

[6] Intaraphan, Piraya. Bankruptcy risk and earning management of Thai listed companies. Master of Accounting Independent study in Commerce and accountancy, Thammaset University; 2014.

[7] Jaisaen, Narumon. Bankruptcy Prediction of the Listed Company in Market for Alternative Investment (MAI) of Thailand. Master of Accounting Independent study in Commerce and accountancy, Thammaset University: 2016.

[8] Jakkapat Phongpatra and Bundit Pungniran. Business Survival Assessment Model. Suthiparithat. 2018: 32(102): 126-139.

[9] Kaiyawan, Yuth. Principle and Using Logistic Regression Analysis for Research. Journal of Rajamangala University of Technology Srivijaya. 2012: 4(1): 1-12.

[10] Nisansala Wijekoon and A. Abdul Azeez. An Integrated Model to Predict Corporate Failure of Listed Companies in Sri Lanka. International Journal of Business and Social Research. 2015: 5: 1-14.

[11] Ohlson, J. A.. Financial ratios and the probabilistic prediction of bankruptcy. Journal of Accounting Research. 1980: 18(1): 109-131.

[12] Rasidah Mohd Said and Mohd Hanafi Tumin. Performance and Financial Ratios of Commercial Banks in Malaysia and China. School of Business, University Kebangsaan Malaysia: 2011. 